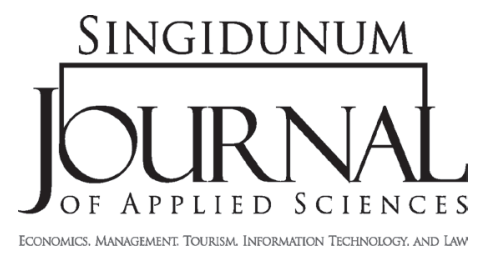

\section{IMPLEMENTATION OF BASEL II STANDARDS IN COMMERCIAL BANKS IN B\&H}

\author{
Radomir Šalić ${ }^{*}$ \\ Sinergija University, \\ Raje Baničića Street, Bijeljina, Bosnia and Herzegovina
}

SINGIDUNUM JOURNAL 2012, 9 (2): 50-62

ISSN 2217-8090

UDK 005.334:336.71(497.6)

Original paper/Originalni naučni rad

\begin{abstract}
:
Based on the study of primary and secondary data from the selected sample of commercial banks, a preliminary statement of the state of the banking system in B\&H has been made for the purpose of determining the current level of application and making the appropriate recommendations concerning the continuation of the implementation of Basel II standards. It has been noted that all banks in the sample give high priority to those standards, that they already have certain knowledge of the area and that they provide constant training to their employees with the aim of enabling full implementation of those standards. It has also been determined that the regulatory authorities in B\&H have not done enough on adopting new regulation related to the area and that operating results of the banks are not satisfactory, especially in terms of rate of return and capital adequacy of banks. Thus, it is recommended that the banks in $\mathrm{B} \& \mathrm{H}$, in addition to their regular activities, collect new sources of funding, especially their own funds or fresh equity since the attraction of other sources does not make much sense without it. Also, the regulatory authorities (banking agencies) should adopt new regulation (decrees), and impose the implementation of new standards in the banking industry together with drafting of specific instructions for the application of individual regulation, preparation of different formats of reports (specific layout of forms) and the implementation of standards and instructions in the banks.
\end{abstract}

\section{Key words:}

Basel Agreement II, banks, risks, capital, deposits, primary and secondary sources.

\section{INTRODUCTION}

After ten years of the implementation of Basel I standards, Basel II standards were introduced. However, they have still not been fully implemented, which is the case not only in Bosnia and Herzegovina, but also in many developed European countries. Basel II standards need to be adjusted to different national markets that are allowed to utilize a certain level of national discretions regarding the manner of implementation. Extensive efforts of both regulatory bodies and banks are required for their consistent application. This document is divided into several parts. Namely, the first part pertains to the findings and observations based on the collected primary and secondary information sources from the banks included in the selected sample. The second part of the document is related to comparison and analysis of data stemming from primary and secondary information sources, while the third part contains recommendations for the continuation of the Basel II standards implementation process.

\section{THE OBJECTIVE AND SCOPE OF RESEARCH}

The objective of this document is to provide some answers and information on important issues concerning the level of implementation of Basel II standards in the banks in Bosnia and Herzegovina, as well as to offer recommendations for their future 
implementation. The research is based on the sample comprising nine commercial banks selected in line with the size and geography criteria.

Taking into consideration the size criterion, all sample banks were classified in relation to the size of their assets. Therefore, they were selected as follows: 4 banks with the size of assets of around 200 million or so called small banks, 3 banks with the size of assets of up to BAM 1 billion or the medium-sized banks, and 2 banks with the size of assets between BAM 1 and 4 billion or large banks. This number of banks represents less than $1 / 3$ or $30 \%$ of all banks in $\mathrm{B} \& \mathrm{H}$. However, from the perspective of value, the BAM 10.7 billion of assets (30/06/2010) from the sample compared to the BAM 20.5 billion (assets of all banks in Bosnia and Herzegovina as of 30/06/2010), represents more than half (52\%) of the banking sector assets in $\mathrm{B} \& \mathrm{H}$. In terms of the geographical criterion, the sample included: four banks from Sarajevo, three banks from Banja Luka, one bank from Mostar and one bank from Bijeljina. Other features of the sample banks include: all banks are shareholding companies; one bank has state- owned capital, while others are mostly banks with private capital; five banks have foreign funding capital, while four banks have capital originating from Bosnia and Herzegovina.

\section{FINDINGS AND OBSERVATIONS}

This paper contains findings and observations obtained from the analysis of the implementation of Basel II Agreement which was conducted on the basis of collected primary and secondary data from the selected sample.

\section{Primary sources of information}

The primary sources of information were collected through the questionnaire and the answers provided in it illustrate the assessment of the current situation, and serve as the basis for the identification of advantages and obstacles in the implementation of Basel II standards. It was completed in direct cooperation with the most senior individuals in the banks with different levels of responsibilities; ranging from heads of departments and directors of different sectors to members and presidents of executive boards. There were 25 questions that are here presented together with the answers in appropriate matrices - tables (such as Table 1 and 2).
However, due to limited space, it was not possible to show them all individually, which is why they are represented in aggregate and synthetic form.

\begin{tabular}{|c|c|c|c|c|}
\hline Bank Responses & High & Medium & Low & Other \\
\hline I A & & $x$ & & \\
\hline II B & & $x$ & & \\
\hline III C & $x$ & & & \\
\hline IV D & & $x$ & & \\
\hline VE & & $x$ & & \\
\hline VI F & $x$ & & & \\
\hline VII G & & $x$ & & \\
\hline VIII H & $x$ & & & \\
\hline$I X \mid$ & $x$ & & & \\
\hline $100 \%$ & 44.4 & 55.6 & & \\
\hline
\end{tabular}

Table 1. Management priority towards Basel II

\begin{tabular}{|c|c|c|c|c|}
\hline Bank Responses & $\begin{array}{c}\text { Excel- } \\
\text { lent }\end{array}$ & $\begin{array}{l}\text { Very } \\
\text { good }\end{array}$ & Good & Other \\
\hline I A & & & $x$ & \\
\hline II B & & & $x$ & \\
\hline III C & & $x$ & & \\
\hline IV D & & & $x$ & \\
\hline VE & & $x$ & & \\
\hline VIF & & $x$ & & \\
\hline VII G & & & $x$ & \\
\hline VIII H & & & $x$ & \\
\hline IX I & $x$ & & & \\
\hline $100 \%$ & 11.11 & 55.56 & 33.33 & \\
\hline
\end{tabular}

Table 2. Level of staff knowledge about Basel II

According to the responses provided in the questionnaire, the majority of the sample banks are giving high priority to Basel II standards and their opinion is that they possess some knowledge and the appropriate level of competence. All banks provide training to their employees in the field of the application of standards, especially for those standards for which they are at the same time experiencing and projecting the largest expenses and the greatest problems. The banks have established special organizational units that are in charge of risk management and they have a relatively high number of employees working in this field.

Regarding the reporting models, it has been noticed that the largest banks by assets in $\mathrm{B} \& \mathrm{H}$ or in terms of our sample, the banks that belong to a certain banking group, report to their mother banks, while the smaller banks do not prepare any forms 
related to Basel II standards, except for the reporting forms imposed by the regulatory bodies, which include only certain elements of Basel II standards. ${ }^{1}$ Some banks that are members of banking groups are developing their own application software for Basel II standards and are submitting only the required data to their mother banks, while some other similar banks receive ready-made format and models for reporting as well as the reporting software.

The credit risk is defined by banks as the default risk of the clients who are not able to service their debt regulated by the contract (Chapman, 2006) or they represent it as the counterparty credit risk measured as the probability that the debtor will not be able to pay interests or the principal amount in accordance with the conditions defined in the loan agreement. Since Basel II standards encourage more flexible methods for credit risk measurement and each bank is advised to use the model suitable for its portfolio, risk preferences and its markets, the answers offered in the questionnaire to the sample banks were as follows: Simplified Standardized Approach (SSA), Standardized Approach (SA), Internal Ratings-Based Approach (IRB) and $A d$ vanced Internal Ratings-Based Approach (AIRBA). The responses showed that the more advanced approach for credit risk measurement was the lower capital requirements were set with the same or not reduced profitability rate. The majority of the banks use Simplified Standardized Approach and those are mostly smaller banks, while the other banks use Standardized Approach. Initially, none of the banks opted for IRB Approach due to the fact that they are well-informed about all necessary requirements and expenses related to the application of more advanced credit risk measurement approaches. Some authors (Gup, 2004) believe that Basel II is not perfect and that it is very complex for practical implementation. Namely, it contains hundreds of pages describing three methods that can be used for calculation of risk-weighted capital. Advanced IRB method for calculation of capital necessary to cover the risk requires large quantities of data and computer models that need to anticipate losses and other relevant factors, and use different methods for calculating capital requirements for loans in order to illustrate different capital needs for the same loan. The costs of implementing Base II standards are high and range from around USD 10 million for small up to USD 150 million or even more for large banks. Therefore, the

1 Capital Adequacy Rate in the part of assets at risk in relation to operational risk. implementation of the Basel Agreement is not simple at all, because the banks in Bosnia and Herzegovina do not possess knowledge, technical or financial resources to implement it in the short term. Consequently, this does not mean that they should not comply with the adopted strategy for the implementation of standards and they should do everything in their power to fully apply the standards in the future. The $2 / 3$ of the sample banks have developed internal methodology for credit risk identification and measurement, and those are mostly larger banks, while the smaller banks do not have such methodologies. The same ratio relates to the level of risk categories required for ranking of debtors, whereas the time required for the banks to make risk assessment and the manner of development of the risk assessment model are different. Hence, 1/3 of the banks still do not have time series for collection of unpaid receivables, while the other banks have determined them, and they usually cover the period from 1 to 3 years.

The responses given by the sample banks show that the market risks are not treated in sufficiently high quality manner. Moreover, the number of staff performing this function also supports this conclusion since their number amounts to only few percentages of all employees involved in risk management. There are different reasons for this including:

- The very low level of banks' investments on financial markets in general, and especially low level of capital market investments, i.e. the market of long-term securities,

- Currency board as a type of monetary authority that does not leave a lot of space for currency rate differences, since the foreign currency rate is fixed and the greatest volume of foreign currency transactions is made in EUR, and much lower volume in other national currencies,

- due to the high level of monetary funds of the banks in the Central Bank of Bosnia and Herzegovina ( $\mathrm{CB}$ mandatory reserves and liquidity reserves) and balances in EUR in the banks abroad; i.e. mostly in the accounts of the mother banks or correspondent banks.

According to the Basel Committee, market risk is the risk of losses in on-balance and off- balance sheet positions arising from movements in market prices. It is limited to the period until the closure of an opened position, and the differences (negative or positive) are higher when the period of their closure (closing of an opened position) is longer. In the past, 
market risk was treated in the traditional manner, meaning that there were individual techniques developed for identification, measurement and protection compared to the Basel II approaches that need to provide for measuring and protection, but also to ensure compatibility with other different financial institutions. The market risks are to the greatest extent pertaining to the investment banks or the banks with a large volume of activities related to the trading book, i.e. activities related to the changes in interest rates, foreign currency rates and stock market indices. In our example, the offered answers for the issue of the selection of market risk approach were: Standardized Method (SMM) and Internal Model Based Approach (IMA). The Standardized Approach for market risk measurement is used by $56 \%$ of the banks in Bosnia and Herzegovina, and the $22.2 \%$ is allocated to both the Internal Model and the banks that did not determine the model. The banks that did not select the model are local banks, i.e. the banks with very low level of activities related to financial market and market risks, and they are operating in line with the existing regulation of Banking Agencies. $^{2}$ Around $33 \%$ of the sample banks did not determine time series for market risk assessment, and other 33\% determined the time series between two and three years, and only $22.2 \%$ of the banks have formed time series for market risk assessment less than one year.

The operational risk in banks is becoming more and more significant and the damages and negative effects are generally larger. It is relatively new and it evolved due to the development of banking, global business operations, and electronic banking operations, development of financial instruments and derivatives, as well as continuous advancement of information systems. It used to be related exclusively to human factor, frauds and thefts, and today it is increasingly the result of the application of advanced computer techniques in combination with the globalization and operations with exotic financial destinations and the inevitable human factor. Therefore, the losses stemming from inadequate management of operation risks in banks are amounting to billions of US dollars. The usual number of employees working on the operational risk management is 2 per bank, and there is no single bank without an employee in charge of operational risk management. The Basel II standards regulate a number of opera-

2 Decree on Minimum Standards for market risk management in banks is still not in force. tional risk management approaches, which were offered in the questionnaire: Basic Indicator Approach (BIA), Standardized Approach (SA), Alternative Standardized Approach (ASA) and Advanced Measurement Approach (AMA). In terms of operational risk management, the largest number of banks (56\%) stated that they use Basic Indicator Approach (BIA) or Standardized Approach (SA). Larger banks or the banks with foreign capital prefer Standardized Approach and potential combination with Advanced Approach, while the smaller, local banks opt for Basic Indicator Approach. Almost the same ratio exists for the preparation of time series required for operational risk assessment.

\section{Secondary sources of information}

The business books as the secondary source of information from the banks are represented through the balances, Balance Sheet and Profit and Loss Statement, which represent in a way the disclosure of banking information (Ranković, 2008). The Balance Sheet provides information on size and share of the assets (funds) of the sample banks in the overall assets of banks in Bosnia and Herzegovina, the structure of assets and liabilities, structure of investments, capital and deposit structure, as well as the application of horizontal and vertical rules of financing. The Profit and Loss Statement includes income, expenses and financial results of banks booked over a certain period and are subject to further disaggregation. Therefore, this document includes and analyses available original data of the sample banks (disclosed to public) for three accounting periods (30/06/2009, 31/12/2009 and 30/06/2010). It also includes information from the reports of the Banking Agency of the Republic of Srpska and the Banking Agency of the Federation of Bosnia and Herzegovina.

\section{Assets of the banks}

According to the official published data, the value of the assets of banks in Bosnia and Herzegovina, on a cumulative basis in 2010 compared to 2009, decreased by $2 \%$ in the Republic of Srpska (Agencija za bankarstvo Republike Srpske, 2011) and by $1 \%$ in the Federation B\&H (Agencija za bankarstvo Federacije Bosne i Hercegovine, 2011). The shrinking of banks' assets in B\&H started in 2008, and continues to the present day. In the Republic of Srpska, the 


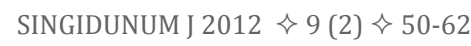

Šalić R. $\diamond$ Implementation of Basel II standards

\begin{tabular}{|c|c|c|c|c|c|c|c|c|c|c|c|}
\hline Description & $A$ & $B$ & C & $\mathrm{D}$ & $E$ & $\mathrm{~F}$ & G & $\mathrm{H}$ & I & $\Sigma$ & $\%$ \\
\hline ASSETS (in millions KM) & I & II & III & IV & $\mathrm{V}$ & VI & VII & VIII & IX & & \\
\hline 1. Cash assets & 62 & 83 & 40 & 57 & 160 & 242 & 296 & 1.140 & 1.186 & 3.266 & 31 \\
\hline 2. Tradable securities & & 1 & & & & 2 & 56 & 44 & 175 & 278 & 3 \\
\hline 3. Placements to banks & 12 & 2 & 17 & 2 & & & 120 & 124 & 19 & 296 & 3 \\
\hline 4. Loans & 81 & 68 & 137 & 143 & 402 & 583 & 613 & 2.132 & 2.392 & 6.551 & 61 \\
\hline 5. Maturity securities & 7 & & & & & & & & 131 & 138 & 1 \\
\hline 6. Fixed assets & 7 & 18 & 10 & 11 & 31 & 28 & 31 & 86 & 149 & 371 & 3 \\
\hline 7. Other real estate & & & & & & & & 7 & 2 & 9 & \\
\hline 8. Invest in-non consol Co & & 1 & 1 & 1 & & 2 & 1 & 2 & 13 & 21 & \\
\hline 9. Other assets & 3 & 1 & 9 & 7 & 4 & 13 & 8 & 47 & 60 & 152 & 1 \\
\hline 10. Minus: Reservations & 3 & 4 & 10 & 9 & 19 & 25 & 42 & 85 & 134 & 331 & -3 \\
\hline Total (from 1 to $9-10$ ) & 169 & 170 & 204 & 212 & 578 & 845 & 1.083 & 3.497 & 3.993 & 10.751 & \\
\hline
\end{tabular}

Table 3. Balance Sheet of banks as of 30. June 2010.

decrease was the result of deposits reduction (9\%) on one side (liabilities) of the balance, and due to that fact the decrease in the funds on the other side of the banks' balances. The lack of deposits in the sources of funding was replaced by new loans and subordinated debts.

In the assets structure, the greatest changes are related to the investments in loans, investments in securities and potential loss reserves. The loan volume was reduced by approximately $3 \%$, and the loan loss reserves were increased by approximately $0,4 \%$ or for around BAM 42 million. Hence, their trend was opposite to the trend of the loans, which illustrates that there was a double deterioration of the situation in the sector. The logic is that when the loan investments are reduced, the loan loss reserves are reduced as well. However, this was not the case, and the loan loss reserves have increased due to the increase in the number of bad loans or NPLs (non-performing loans), and this number is still growing. Consequently, this is significantly reducing already very low profitability rate of the B\&H banks. On an aggregate basis, the loans of the sample banks amount to BAM 6.5 billion or $61 \%$ of the total assets or $94 \%$ of the total investments of the banks. The loan loss reserves were at that same period around 3.1\%, which is low and insufficient having in mind the existing volume of loans and the fact that the number of so called bad loans $(C$, $\mathrm{D}$ and $\mathrm{E}$ ) is getting higher. At first glance, it is quite obvious that the loan loss reserves presented in the Balance Sheets of the banks are significantly underestimated, because the aforementioned implies that almost all loans are categorized in A and B category, which is unrealistic and impossible.
The level of cash in the sample banks' assets is high and has never been below 30\%. The reasons for that could be found in the existing regulation of the B\&H Central Bank (mandatory reserves level), increased volume of liquidity reserves and the high level of funds from abroad resulting from different balances on the accounts at the correspondent banks, but also at mother banks which are placed on the accounts because of the specific needs of the shareholders. Almost the same situation is evident when we look at the individual banks, since the structure of the assets literally consists of two positions, i.e. investments (loans and securities) and cash assets. All other positions in the structure of assets are negligible. Nevertheless, if we want to present them in more detail, we can divide the structure of assets into: cash, securities, and loans, fixed and other assets.

The presented data illustrate to which extent the individual banks are conservative or unwilling to accept the complexity and the challenges of banking business, and that the amounts of the funds held in the accounts in the Central Bank and other banks were higher than the amounts of funds invested in loans and securities. The banks did not get much return on most of these assets since they were getting minimum fees for deposits for keeping the funds in the accounts of the Central Bank and other banks, and more than that, they have actually lost significant profit.

The level of investments in securities was also low. However, it increased from one reporting period to another, which is illustrated through its share in assets which was $0.4 \%$ as of $30 / 06 / 2009$, and two 


\begin{tabular}{|c|c|c|c|c|c|c|c|c|c|c|c|}
\hline Description & $A$ & B & $\mathrm{C}$ & $D$ & $\mathrm{E}$ & $\mathrm{F}$ & G & $\mathrm{H}$ & 1 & $\Sigma$ & $\%$ \\
\hline LAIBILITIES ( mill KM) & 1 & II & III & IV & V & VI & VII & VIII & IX & & \\
\hline 1. Deposits & 97 & 119 & 157 & 154 & 429 & 592 & 819 & 2.678 & 2.805 & 7.850 & 73 \\
\hline 2. Loans & & 2 & 17 & 4 & 68 & 159 & 144 & 194 & 660 & 1.248 & 12 \\
\hline 3. Subordinated debts & & & & 1 & & 1 & 10 & 27 & 93 & 132 & 1 \\
\hline 4. Other liabilities & 4 & 4 & 5 & 3 & 13 & 15 & 27 & 218 & 69 & 358 & 3 \\
\hline 5. Total Capital & 68 & 45 & 25 & 50 & 68 & 78 & 83 & 380 & 366 & 1.163 & 11 \\
\hline Regular shares & 60 & 34 & 23 & 43 & 62 & 53 & 52 & 119 & 239 & 685 & \\
\hline Premium asio & & & & 4 & 1 & 8 & & 48 & 5 & 66 & \\
\hline Undistributed profit & 8 & 11 & 2 & 2 & & 14 & 5 & 200 & 124 & 366 & \\
\hline Capital reserves & & & & & 5 & 3 & 26 & 13 & & 47 & \\
\hline Other capital & & & & 1 & & & & & & 1 & \\
\hline Total $(1+5)$ & 169 & 170 & 204 & 212 & 578 & 845 & 1.083 & 3.497 & 3.993 & 10.751 & \\
\hline
\end{tabular}

Table 4. Balance Sheet of as of 30. June 2010.

accounting periods later (on 30/06/2010) it was 3.9\% $(2.6+1.3)$ of the total assets of the sample banks. On an individual basis, some banks invested negligible funds to this end, so that they are not even visible, but on the cumulative basis some progress is evident.

The share of fixed assets in the total assets is much larger at small banks than at larger banks, and this did not lead to adequate profit and did not contribute to the success of the banks, especially in the events when the banks had low investments in loans and other activities that are more lucrative for the banks.

Liabilities or the sources of funding of the sample banks are at first glance better quality part of the Balance Sheet, especially if deposits are taken into consideration since they represent $73 \%$ of liabilities (Table 4) and their volume is sufficient not only to cover loan investments, but also investments in securities and fixed assets. Also, if we take into account the fact that the part of the funding sources is held in the accounts of the Central Banks and other banks. This implies that funds in the accounts of the banks are covering the capital and loans from other banks, which also makes sense and justifies the horizontal financing rules.

If capital is a security buffer for a bank against the reduction of its assets (Mishkin, 2010), in cumulative terms the sample banks have sufficient capital. However, if we look at the structure of the capital in the banks, it is evident that most of the banks are actually lacking capital and this represents the condition for the future growth of the banks' assets. Namely, some banks have capital amounts that are at the lower end of the required capital amounts, and every additional activity aimed at increasing other financing sources (deposits, loans) remains unobserved or with no results.

This means that every new loan investment reduces the capital adequacy rate of those banks, which means they are not going to be in the position to develop and grow in accordance with the intentions of the shareholders and the management unless they increase their capital.

It is obvious that the capital of the sample banks in most of the cases is share capital i.e. the capital stemming from the issue of the shares at the point of the establishment or the purchase of banks at the secondary capital market. Also, some of the banks did not enlarge their capital since the establishment, due to either poor business results or payout of dividends to shareholders from the profit. However, there are some banks that retained all earnings at the banks, and thus managed to increase their capital.

The deposits are "the basis for the development and growth of the banks (Rose, 2003, p.387) and they are providing for most of the "raw material" for the banks' loans through their network of subsidiaries, branches and agencies. Therefore, the commercial banks in $\mathrm{B} \& \mathrm{H}$ have mobilized deposits in local currency as well as in foreign currencies. Throughout the observed period, the commercial banks have maintained or increased their sources of funding, mostly through deposits of the banks abroad (mother banks), the accounts of the Entities' governments and their institutions, and through citizens' deposits. The interesting aspect is the fact that the deposits of the private companies are at low level and are declining. The deposits are clas- 


\begin{tabular}{ccccccc}
\hline \multirow{2}{*}{ Banks } & & $\begin{array}{c}30.06 . \\
2009 .\end{array}$ & $\begin{array}{c}31.12 \\
2009 .\end{array}$ & $\begin{array}{c}30.06 . \\
2010 .\end{array}$ & \multicolumn{2}{c}{ Index } \\
\cline { 6 - 8 } I & 2 & 3 & 4 & 5 & 6 & 7 \\
\hline I & A & 55.5 & 52.8 & 54.0 & 95 & 102 \\
\hline II & B & 44.0 & 40.5 & 38.8 & 92 & 96 \\
\hline III & C & 14.7 & 18.7 & 15.5 & 127 & 83 \\
\hline IV & D & 37.7 & 32.7 & 28.4 & 87 & 87 \\
\hline V & E & 15.6 & 15.9 & 14.8 & 102 & 93 \\
\hline VI & F & 13.6 & 15.1 & 12.6 & 111 & 83 \\
\hline VII & G & 14.4 & 15.5 & 13.9 & 108 & 90 \\
\hline VIII & H & 14.6 & 15.3 & 14.8 & 105 & 97 \\
\hline IX & I & 15.0 & 14.2 & 14.8 & 95 & 104 \\
\hline Table 5 & Capital Afequacy Ratio (CAR) & &
\end{tabular}

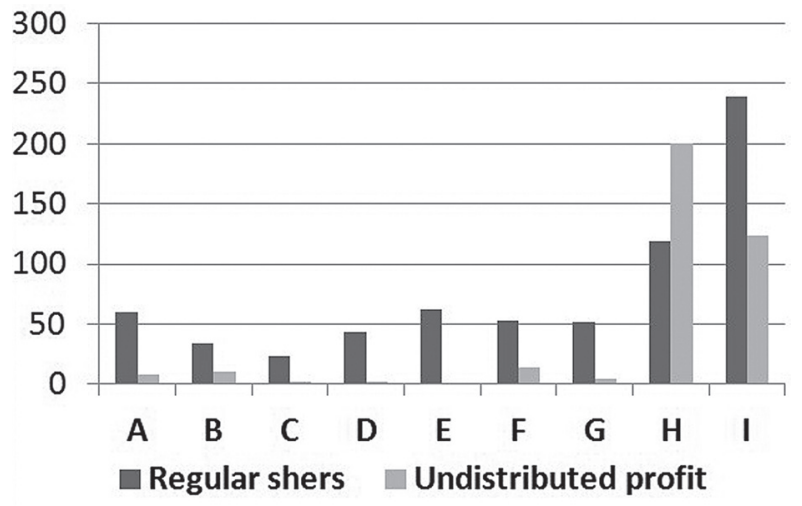

Chart 1. Capital structure

sified into: interest-bearing deposits that account for $90.8 \%$ and non-interest bearing deposits which stand for $9.2 \%$ of all deposits. The two largest banks in the sample have the largest share in deposits, and at the same time those banks have the largest capital as a result of a great extent of business operations (profit), which enabled them to mobilize the majority of the total or available deposits in Bosnia and Herzegovina.

\section{Financial position of banks}

The business results of the sample banks are presented in the Balance Sheets for the observed periods, but they are similar and concurrent in the amounts and in the structure, and because of that they are here illustrated only for the period 01/01 to $30 / 06 / 2010$. In aggregate terms, the Balance Sheet shows that the banking sector can function and make fresh profit, as it was the case during the time, but the question here is whether the profit is sufficient and whether there is a possibility to make it even higher? Most probably yes, but the level of economic activity is still very low and far cry from the pre-war level (before 1992), since there is only a small number of companies that are making larger transactions of funds and that represent large and broad deposit basis of the banks. ${ }^{3}$

More than two thirds of the total income (69\%) consisted of income from accrued interests, while the other part of the income (31\%) came from fees for internal and foreign payment transactions. This means that the sample banks made most of their

3 UNIS, Energoinvest and UPI had dozens and hundreds of thousands of employees up to 1992.

earnings from differences or positive effects of the accrued active and passive interests, i.e. interest spread, and the much smaller part of net income was made from commissions and fees. The abovementioned income is low and barely sufficient to cover the expenses. Hence, the final result is low profit of around BAM 25 million. The largest part of expenses are operational expenses such as salaries and social contributions, and material expenses in the percentage of around $47 \%$ of the total expenses , which demonstrates the traditional labor-intensive nature of the banks. The so -called business and direct expenses cannot be neglected as well, and their greatest share is allocated to potential loss reserves that are underestimated and should be much higher. This example illustrates that if the loss reserves increased, the final result would be much worse, i.e. the bottom line would represent a loss for the banks and this would have additional negative consequences.

The profitability indicators are at extremely low level. However, if any of the expenses from the total expenses structure was higher, the profitability indicators would not exist at all, and one would assume that this can easily and promptly occur. According to data from B\&H Association of Banks, the achieved profitability ratios at the level of Bosnia and Herzegovina in the last couple of years are more than devastating, since the return on average assets (ROAA) of the B\&H banks for 2009 was $0.1 \%$, and return on average equity (ROAE) was $0.8 \%$. According to the rules of the matrix of optional yield and risk relation (Rose, 2003), the ratio of assets to capital for B\&H banks and ratio of assets to equity from the sample is approximately 10:1 (Chart and 


\begin{tabular}{lrrrrrrrrrr}
\hline $\begin{array}{l}\text { Revenues and expenditures } \\
\text { (000 KM) }\end{array}$ & $\begin{array}{r}\text { A } \\
\text { I }\end{array}$ & $\begin{array}{r}\text { B } \\
\text { II }\end{array}$ & $\begin{array}{r}\text { C } \\
\text { III }\end{array}$ & $\begin{array}{r}\text { D } \\
\text { IV }\end{array}$ & $\begin{array}{r}E \\
\text { V }\end{array}$ & $\begin{array}{r}F \\
\text { VI }\end{array}$ & $\begin{array}{r}\text { G } \\
\text { VII }\end{array}$ & $\begin{array}{r}H \\
\text { VIII }\end{array}$ & $\begin{array}{r}\text { I } \\
\text { IX }\end{array}$ & $\begin{array}{r}\Sigma \\
\text { 1. Revenues from interest }\end{array}$ \\
\hline 5.073 & 3.236 & 6.961 & 6.296 & 18.535 & 21.274 & 28.343 & 93.350 & 111.315 & 287 \\
\hline 2. Interest expenditures & 1.438 & 1.367 & 2.333 & 2.112 & 6.335 & 9.534 & 12.310 & 32.496 & 48.038 & 108 \\
\hline 3. Net interest income 1-2 & 3.635 & 1.869 & 4.628 & 4.184 & 12.200 & 11.740 & 16.033 & 60.854 & 63.277 & 178 \\
\hline 4. Operational revenues & 2.506 & 4.647 & 9.763 & 1.777 & 6.150 & 12.340 & 10.636 & 39.454 & 37.705 & 124 \\
\hline 5. Non interest expenditure & 5.612 & 6.126 & 13.886 & 5.499 & 17.824 & 19.042 & 21.157 & 88.216 & 100.893 & 278 \\
\hline 6. Profit before tax:3+4-5 & 529 & 390 & 505 & 462 & 526 & 5.038 & 5.512 & 12.092 & 89 & 25 \\
\hline 7. Loss & & & & & & & & & & \\
\hline 8. Taxes & 52 & 60 & 26 & 71 & 186 & 633 & 551 & 1.209 & 8 & 2 \\
\hline 9. Net profit & 581 & 330 & 479 & 391 & 340 & 4.405 & 4.961 & 13.301 & 81 & 24 \\
\hline
\end{tabular}

Table 6. Profit and loss statement as of 30. June 2010.

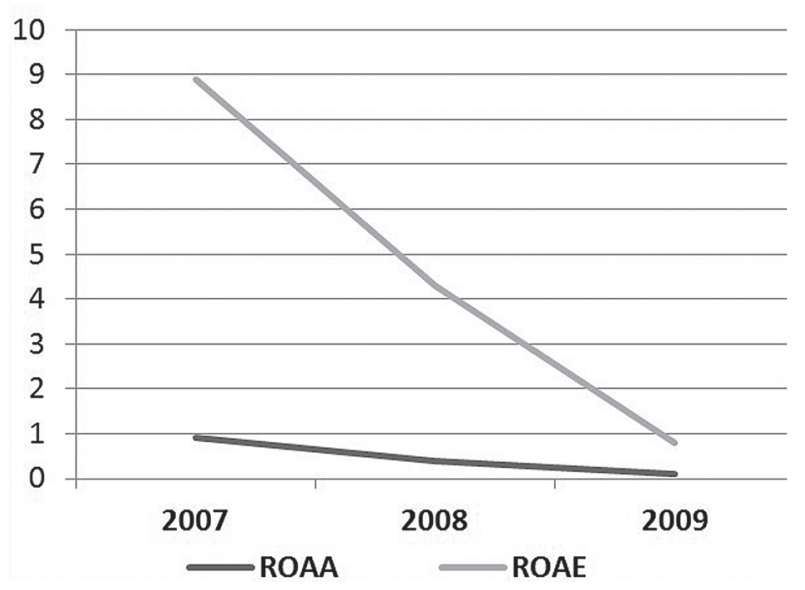

Chart 2. Profitability of banks in B\&H

Table 7). Therefore, the yield on assets should be minimum $0.5 \%$, and in that case the yield on equity should be minimum $5 \%$, which is far cry from the results achieved in the banking sector in Bosnia and Herzegovina. In addition, this illustrates how bad the financial results of $\mathrm{B} \& \mathrm{H}$ banks are, i.e. the extent to which the $\mathrm{B} \& \mathrm{H}$ banks and the sample banks are unprofitable.

These are cumulative results for Bosnia and Herzegovina and for our sample. However, the fact is that there are banks in $\mathrm{B} \& \mathrm{H}$ that are achieving excellent financial results, i.e. the banks that meet the requirement of the yield and risk ratio in line with the theoretical rules presented in the previous Table.

\section{ANALYSIS OF THE SITUATION}

A couple of basic features are evident based on the review and comparison of primary (questionnaire) and secondary data (business books) of the sample banks:

\begin{tabular}{|c|c|c|c|c|}
\hline \multirow{2}{*}{$\begin{array}{l}\text { Ratio be- } \\
\text { tween assets } \\
\text { and equity }\end{array}$} & \multicolumn{4}{|c|}{ ROE with ROA (in \%) } \\
\hline & 0,5 & 1,0 & 1,5 & 2,0 \\
\hline $5: 1$ & 2.5 & 5.0 & 7.5 & 10.0 \\
\hline 10:1 & 5.0 & 10.0 & 15.0 & 20.0 \\
\hline $15: 1$ & 7.5 & 15.0 & 22.5 & 30.0 \\
\hline $20: 1$ & 10.0 & 20.0 & 30.0 & 40.0 \\
\hline
\end{tabular}

Table 7. Ratio rules and options

- the banks that are realizing better business results, higher income and higher profit are the banks that possess larger assets and larger sources of funding (capital, deposits); and those banks are already implementing Basel II standards on consolidated basis. Therefore, at this point in time, they are more prepared and more up-to-date in terms of: a) the approaches they use for risk management, b) the duration of the time series for risk assessment and c) development of the model for the assessment of the risk coverage in banks. The larger sample banks are at the same time the banks with high concentration of loans and deposits and with market position that almost represents monopoly, and they are also the most secure banks for their depositors. This is mostly the case because the volume of business operations they are realizing is satisfactory, but with relatively low capital adequacy ratios ranging from 12.6 to $14.8 \%$ 
(Table 5). Every subsequent change in the structure of the assets of the banks directed at the decrease of the cash assets and increase of the loans would simply lead to reduction of capital adequacy ratio to the limit of $12 \%$, which represents an alert for the banks to modify the balances in terms of capital increase, especially the capital base, which is hardly feasible for many banks today.

- the small or the smaller sample banks are in much more inferior position regarding the Basel II application compared to the larger sample banks, and except for the capital in the liabilities structure they do not have other significant sources of funding (deposits, loans). Due to the previously mentioned fact, the small banks are realizing high capital adequacy rates ranging from 28 to $55 \%$. These banks apply totally conservative management approach since they did not use the capital they have to increase the volume of the total assets of the banks. How? If the average net capital of small banks is around BAM 48 million $^{4}$, then their assets at risk may be around BAM 400 million, and the total assets of the banks should be even higher because the total assets of all sample banks are higher than total risk assets, disregarding the fact that the risk assets of the banks include the off-balance positions as well, and we did not take those positions into consideration at all. ${ }^{5}$ The level of total assets of (small) banks ranges from BAM 170 to 212 million, which implies that their balances could have been at least $100 \%$ higher or even double of the existing amount. Therefore, the fact remains that these banks did not perform good quality operations in terms of the main activity of the banks, i.e. mobilization of the sources, and especially deposits which are essential for the functioning of any bank. Those deposits are placed in other, larger banks, but this does not mean that the division of the deposits could not have been different, i.e. more deposits in the smaller banks, since this would make all other results more favorable and would be

4 With the assumption that: the net capital (NC) is BAM 48.000 .000 , that $\mathrm{CAR}=12 \%$, risk assets $(\mathrm{RA})=\mathrm{NC} / \mathrm{CAR}^{\star} 100$ $=$ BAM $400.000 .000, \mathrm{CAR}=\mathrm{NC} / \mathrm{RA}=0.12$ or $12 \%$

5 The banks in the Federation $\mathrm{BiH}$ did not present offbalance positions in their balances (short version), compared to RS banks that have included those positions in their forms, therefore, there was no sense to consider those since the balance data would be incomparable. reflected in higher level of investments, and consequently higher earnings, profits and its distribution. Moreover, the statement of some analysts claiming that "traditional banking practices based on deposits mobilization and investments in loans represent only one part of typical banking operations and are at the same time the least profitable (Greuning and Bratanović, 2006, p.2) is not valid for our example of the banking sector in $\mathrm{B} \& \mathrm{H}$. The deposit mobilization and placement of those into loans definitely represent significant activity of all B\&H banks;

- the information that all, and especially the small sample banks, had huge cash assets (compared to their total balances) available at the end of the accounting periods supports the fact that they not only failed to collect new sources, but also to use the existing ones in order to achieve better business results. Additionally, even the large sample banks do not have logical explanation for the fact that they are holding large portion of total funds in the form of cash assets, especially for the amount of funds deposited in the accounts of other banks abroad or in the accounts of mother banks, i.e. the banks that have founded them. The cash assets placed on the accounts of correspondent banks are logical and have their purpose. However, the funds that are "lying" in the accounts of mother companies from the perspective of an ordinary observer or an external analyst do not make much sense and are not sufficiently transparent in terms of their function or their role. This is a problem of the banks and their supervisory boards, and audit committees, and in some cases probably the problem of the regulatory bodies. ${ }^{7}$ Hence, without specific analysis and more information one could not decide on the purpose and logic behind holding of such high amounts of cash assets in general. The issue is that the banks are holding highly liquid assets in inappropriate percentages (even up to 35\%) of the total assets, and by doing so they are provoking damages and unnecessary expenses to themselves,

6 The large part of the cash assets that the local banks keep on the accounts of their mother companies have very low turnover rates and are making low or no profit at all.

7 Regulatory bodies should in addition to formal checks and off-site controls, conduct qualitative control of cash assets and also its balances abroad. 
- Risks mostly refer to credit, market and operational risks which need to be continuously identified, quantified and monitored. These activities require the existence of strategies, sound policies, adequate organization, good quality procedures, experienced analysts and the appropriate information-technology support. The sample banks mostly use simple risk measurement approaches, and the larger banks are seriously getting prepared for full implementation of new standards once the legal preconditions have been created ${ }^{8}$, so they are: developing and improving risk coverage models, introducing new application software and hardware, and determining time series for the assessment of credit, market and operational risks. Larger banks are more advanced in this regard, compared to the smaller banks, since they are investing significant amounts into development of information technologies as the future basis for risk management, and over the period of last couple of years they have been collecting data in order to create time series; whereas the smaller banks still do not have any time series for the assessment of any of the risks,

- in the selected sample of ${ }^{9}$ commercial banks there were certain changes in the assets size, more in the sense of their structure than of its total value, caused by different factors and the market concentration stands out as one of the most important factors. The high degree of concentration, in general, has a negative connotation because the concentration in the banking industry may have an impact on the economic growth, and this depends to the greatest extent on the economic development level of individual countries. Since the concentration in banking has broader and more complex implications on the efficiency and stability of the overall financial system, the $\mathrm{B} \& \mathrm{H}$ market concentration of the sample banks was prepared based on HHI index9 (Herfindahl-Hirschman Index) for three basic segments of business operations, i.e. loans,

8 The new decrees of the $\mathrm{B} \& \mathrm{H}$ regulatory bodies for the implementation of Basel II are expected to be prepared and adopted in accordance with the adopted Strategy for introduction of the "International Convergence of Capital Measurement and Capital Standards" Basel II.

9 The most famous indicator of industry concentration is Herfindahl-Hirschman Index (HHI), and it often serves as a starting point for defining other concentration indices. deposits and total assets of the sample banks (Table 8 ). The value of the HHI should not be over 1800 units, because if it is higher than that, then it is deemed that some of the banks could apply prices that are higher than competitive level over certain period of time. It is being calculated in line with the following formula:

$$
H=\sum_{i=1}^{N} s_{i}^{2}
$$

where $s$ is the share of $\mathrm{i}$-th bank on the market, and $\mathrm{n}$ is the total number of banks. The indices for our sample are as follows:

\begin{tabular}{cccc}
\hline Structure & $\mathrm{VI} / 2009$ & $\mathrm{XII} / 2009$ & $\mathrm{VI} / 2009$ \\
\hline Loans & 2821 & 2661 & 2608 \\
\hline Deposits & 2569 & 2598 & 2648 \\
\hline Assets & 2747 & 2683 & 2640 \\
\hline
\end{tabular}

Table 8. HHI for the period

The previous Table shows that the HHI concentration indices in this sample are very high and that they are very evident in the sample because there are two large banks being compared with much smaller banks. However, the market concentration indices calculated by the $\mathrm{B} \& \mathrm{H}$ regulatory bodies are also high and above moderate and acceptable levels, but lower than indices in our sample due to different structure of banks. ${ }^{10}$

- some of the sample banks have maturity mismatch between assets and financing sources, i.e. between long-term sources and long-term investments. More specifically, when we look at the maturity compliance of B\&H banks (e.g. RS banks) as of 30/06/2010, it is obvious that there is a violation of the financing horizontal golden rule, ${ }^{11}$ i.e. that the long-term financing sources are not covering for long-term investments.

10 According to the RS Banking Agency, the HHI of loans for the same period is 1956 units (above 1800) and in the structure of ten banks there is no single large bank with the size of the banks from our sample.

11 The most important horizontal financing rule for banks is the golden financing rule and in line with it in order not to be at risk of defaulting, the loans that a bank is disbursing must correspond to the amount and the quality of the loans that a bank has taken. 
Even if we include capital and long-term subordinated debts in the long-term sources, on top of the long-term deposits, the long-term investments are still not fully covered, or are covered with at most around $75.6 \%$ of long-term sources (Table 9). This means that there is more intense spill-over of one sources to others, i.e. that the long-term investments are being financed from short-term sources, and as a rule this leads to illiquidity and deterioration of assets classification and to the negative financial result.

\begin{tabular}{lclc} 
A) Long-term placements (KM) & \multicolumn{2}{c}{ B) Long-term sources } \\
\hline $\begin{array}{l}\text { Long place- } \\
\text { ments }\end{array}$ & 2.924 .933 & $\begin{array}{l}\text { Long-term } \\
\text { deposits }\end{array}$ & 1.781 .065 \\
\hline Fixed assets & 199.721 & Capital & 571.810 \\
\hline & $\begin{array}{l}\text { Subordinat- } \\
\text { ed debts }\end{array}$ & 10.841 \\
\hline $\begin{array}{l}\text { Total Long- } \\
\text { term place- } \\
\text { ments }\end{array}$ & 3.124 .654 & $\begin{array}{l}\text { Total Long- } \\
\text { term sources }\end{array}$ & 2.363 .716 \\
\hline
\end{tabular}

Coverage of Long-term placements with sources B/A

$75.64 \%$

\section{Table 9. Maturity compliance of RS Banks} as of 30. June 2010.

If we apply the ratio to our sample, we get to a conclusion that the banks are lacking good quality financing sources, i.e. long-term financing sources and longer term and more stable deposits, long-term credit lines, as well as capital, especially the capital from primary issue of shares and capital from realized profit.

\section{RECOMMENDATIONS}

Bearing in mind the Strategy for the introduction of "International Convergence on Capital Measurement and Capital Standards" Basel II and the deadlines set in this document, one can state that the banking system in $\mathrm{B} \& \mathrm{H}$ is still in the first phase of the implementation of the Strategy (2009 -2013). Actually, it is in the phase that is ongoing and during which the banks and the regulatory bodies are making gradual adjustments and developing their capacities. The recommendations that could lead to faster and more effective implementation of the standards are as follows:
1. It is necessary to continue with the engagement of the USAID - PARE Project staff in the area of financial and expert assistance to all banking structures in Bosnia and Herzegovina for the development of framework by-laws (decrees) related to all segments of Basel II standards implementation, as well as for drafting of specific instructions for the application of individual regulation, and the preparation of different formats of reports (specific layout of forms) and the implementation of standards and instructions in the banks, in order to avoid the situations in which the regulation adopted and published are not implementable in practice and whose application is postponed for years. ${ }^{12}$

2. Since some of the sample banks are already applying Basel II standards, but on consolidated basis and since they already have appropriate forms for reporting to their mother companies based on EU Directives with the explanations i.e. legal remarks for all forms as a basis for their creation, the recommendation to the regulatory bodies and future authors of the instructions is to create those forms in a similar manner and to adjust them to domestic environment i.e. to exclude the unnecessary columns or the ones for which it is sure that they are not going to be used in the near future ${ }^{13}$, and to make them more clear and functional.

3. The special problem is the application software that needs to support all mentioned and future reports. However, most of the banks do not have that software, especially those banks that do not have mother companies abroad. Many banks did not even start with the analysis of the problem because they do not have sufficient information on the system or the reasons for software development or on the predefined information that needs to be obtained from the system. It is not possible to develop software for the small banks since they do not have the information about the format of the reports required by the regulators in the country. Also, the fact is that some banks have internally developed software for risk assessment, however, the question is what is the quality of those and whether the banks should, once the regulators adopt new regulation, com-

12 The Decree on Minimum Standards for Market Risk Management in Banks was adopted in May 2008, and its implementation was postponed on three occasions and even today it is not being implemented.

13 There are commercial banks that are already filling in the reports for the purpose of consolidated balance, but out of 23 columns they are using 12, and 11 are not being used since there is no need for that. 
pletely or partially abandon their software solutions, whether they in general have the data base that is compliant with other software solutions and whether that is going to be more manual or automatic data input processing in order to get appropriate information related to Basel II standards requirements.

4. Besides the abovementioned, there are other activities that banks in B\&H need to conduct. Actually, the banks need to attract new sources of funding because without them they will not be able to maintain the existing level of operations. In addition, special attention should be given to collection of own funds or fresh equity since the attraction of other sources does not make much sense without it. The capital is the benchmark for any future total growth of assets, i.e. the capital adequacy ratio is that benchmark, or the indicator determining what the banks should do and when to do it. Large or larger banks in $\mathrm{B} \& \mathrm{H}$ need capital today since their capital adequacy ratios are low (close to 12\%) and if the existing financial crisis that is very much evident in our region is prolonged, the assets classification of the banks will be deteriorated as well as the financial results, i.e. there will be losses that most of the banks will not be able to cover by the results of the current year, and they will have to reduce capital. This will lead to reduction of the capital portion in the risk assets down to the level that will not be satisfying for the benchmarks determined by the regulatory bodies. The fact is that a number of years after the purchase or the privatization many banks failed to increase their capital even for $1 \%$, which is incomprehensible and deserves strong criticism. The question that one can raise is why privatization or the purchase of the domestic banks? What are the results of the banks? Are they really that incompetent that they cannot make profit in the country where the interest rates and commission spreads are much higher than in their countries of origin, or whether there are some other reasons behind this? What are the regulators doing and is there a chance for higher transparency in the banks? Consequently, unclear and nontransparent actions of the banks, low level of capital of other banks and underdeveloped financial and banking market in $\mathrm{B} \& \mathrm{H}$ are the explanations for modest total assets of $\mathrm{B} \& \mathrm{H}$ banks. Following the attraction of capital, all $\mathrm{B} \& \mathrm{H}$ banks will have to seek and fight for new, other or somebody else's financing sources i.e. for new deposits and new sources of good quality long-term assets. This activity is even more important for smaller banks since they need to provide better quality services and apply more aggressive approach in the banking market in order to fight for different and more beneficial reallocation of deposits. If they are not able to take those steps, they should look around for the merging options in order to save themselves form complete disappearance from the market.

\section{CONCLUSION}

The commercial banks in Bosnia and Herzegovina have definitely accepted international banking standards, but they are not all at the same stage of preparation for their implementation, or at the same level of development at this point in time. However, disregarding that fact, all banks want the application of new standards and they are all ready, some to a greater extent and some not, to face the new challenges related to capital requirements and risk management in banks. The reasons for wide acceptance lie in the fact that the standards are introduced as the best practice of the best banks in the world that they are being applied by all EU members and $\mathrm{B} \& \mathrm{H}$ is aspiring to become a member country. Also, most importantly, the standards are offering better quality models for maintaining financial strength and financial stability of each individual bank.

The length of the implementation process for the new standards and the manner in which it will be conducted, i.e. which model a bank will accept, does not depend only on banks, but also on other stakeholders in the process, and without them it is impossible to start with the implementation process. These stakeholders include legislative or regulatory bodies of the country, firstly the Banking Agencies of both Entities. It is their task to adopt new regulation (decrees) and impose the implementation and the application of the new banking standards. It is not clear when the mentioned Agencies will be in position to offer such a document, but that document or a set of documents need to be offered as soon as possible, because the commercial banks will not have sufficient time or other resources to meet the adopted standards and set deadlines pertaining to the implementation of new standards. This is the case because simultaneously with the introduction of new standards, the banks need do their main ac- 
tivity that is actually enabling them to reach positive business results and to survive in the future, and that is labor and technology intensive process. The sample banks do not have the same human or technology capacities, and therefore, they cannot accept and implement the new banking standards at the same pace.

\section{REFERENCES}

Agencija za bankarstvo Republike Srpske (2011) Izvještaj o stanju u bankarskom sektoru Republike Srpske za period od 01.01. do 30.06.2010. Banja Luka: Agencija za bankarstvo Republike Srpske [online]. Available from: http://www.abrs.ba/publikacije/Izvjestaj_o_stanju_bankarskog_sistema_RS_30062010_lat.pdf [accessed 29 June 2012]. (in Serbian)

Agencija za bankarstvo Federacije Bosne i Hercegovine (2011) Informacija o bankarskom sistemu Federacije Bosne i Hercegovine: stanje 31.12.2010. Sarajevo: Agencija za bankarstvo Federacije $\mathrm{BiH}$ [online]. Available from: http://www.fba.ba/images/Publikacije_Banke/Informacija_bank_31122010_bos.pdf [accessed 5 May 2012]. (in Serbian)

Gup, B.E. (2004) The New Basel Capital Accord. New York: Thomson.
Chapman, R.J. (2006) Simple Tools and Techniques for Enterprise Risk Management. Chichester: Wiley.

Đukić, Đ. (2007) Upravljanje rizicima i kapitalom u bankama. Beograd: Beogradska berza. (in Serbian)

Lukić, R. (2009) Bankarsko računovodstvo. Belgrade: Faculty of Economy. (in Serbian)

Mishkin, F.S. (2010) Ekonomija novca, bankarstva i finansijskih tržišta. 8. izd. Zagreb: MATE. (in Croatian)

Ranković, J. (2008) Teorija bilansa. 11. izd. Belgrade: Faculty of Economics, University of Belgrade. (in Serbian)

Rodić, J. (1997) Teorija i analiza bilansa. 3. izd. Belgrade: Privrednik. (in Serbian)

Rose, P.S. (2003) Menadžment komercijalnih banaka. 2. izd. Zagreb: MATE. (in Croatian)

Samuels, J.M. (1991) Management of Company Finance. 5th ed. London: Chapman and Hill.

Van Greuning, H., Brajović-Bratanović, S. (2006) Analiza i upravljanje bankovnim rizicima: pristupi za ocjenu organizacije upravljanja rizicima i izloženosti financijskom riziku. 2. izd. Zagreb: MATE. (in Croatian)

Šalić, R. (2011) Monetarna ekonomija i bankarstvo. Čačak: Visoka poslovna škola strukovnih studija iz Čačka. (in Serbian)

\section{PRIMENA STANDARDA IZ BAZEL II SPORAZUMA U POSLOVNIM BANKAMA U BIH}

\section{Rezime:}

Na bazi istraživanja i proučavanja primarnih i sekundardnih podataka iz odabranog uzorka poslovnih banaka, urađena je preliminarna konstatacija stanja bankarskog sistema $\mathrm{BiH}$ u svrhu saznanja dosadašnjeg nivoa primene i davanja odgovarajućih preporuka za nastavak primene standarda Bazelskog sporazuma 2. Konstatovano je da sve banke iz uzorka visok prioritet daju pomenutim standardima, da već raspolažu sa određenim znanjima iz te oblasti i da kontinirano edukuju zaposlene, upravo za potrebe potpune primene tih standarda. Takođe je konstatovano da regulatorni organi $\mathrm{BiH}$ do sada nisu učinili dovoljno na donošenju novih propisa vezanih za tu oblast kao i da poslovni rezultati banaka nisu na zadovoljavajućem nivou, naročito u pogledu stopa profitabilnosti i stopa adekvatnosti kapitala banaka. Zato je preporučeno da banke $\mathrm{BiH}$, pored redovnih aktivnosti treba da prikupljaju nove izvore sredstava, a naročito vlastite, odnosno svež kapital bez kojeg prikupljanje ostalih izvora nema smisla, a regulatorni organi (agencije za bankarstvo) da donesu nova akta (odluke) kojima će se naložiti definitivan početak primene novih standarda u bankarstvu uz izradu konkretnih uputstava za primenu pojedinih akata, sačinjavanje forme izveštavanja (konkretan izgled obrazaca) i implementaciju standarda i uputstava u samim bankama.

\section{Ključne reči:}

Bazelski sporazum II, banke,

rizici,

kapital, depoziti, primarni i sekundarni izvori. 